\title{
Design, Synthesis, Characterization and in vivo Antidiabetic Activity Evaluation of Some Chalcone Derivatives
}

\author{
Semere Welday Kahssay' \\ Gebremedhin Solomon Hailu ${ }^{2}$ \\ Kebede Taye Desta ${ }^{3}$ \\ 'Mizan-Tepi University, College of Health \\ Sciences, School of Pharmacy, \\ Department of Pharmaceutical \\ Chemistry, Mizan-Aman, Ethiopia; \\ ${ }^{2}$ Mekelle University, College of Health \\ Sciences, School of Pharmacy, \\ Department of Medicinal Chemistry, \\ Mekelle, Ethiopia; ${ }^{3}$ Adama Science and \\ Technology University, College of Applied \\ Science, Department of Applied \\ Chemistry, Adama, Ethiopia
}

Background: Diabetes is one of the growing health problems worldwide, and scientists have been striving to find effective treatment methods. In this regard, chalcones have frequently been targeted by many researchers owing to their diverse biological activities.

Methods: Here, the Claisen-Schmidt condensation reaction was applied to synthesize five chalcone derivatives. The chalcone derivatives were evaluated for their relative antidiabetic activities in vivo using streptozotocin (STZ)-induced diabetic mice. Besides, the compounds were assessed for their reduction in postprandial hyperglycemia at 50 and $100 \mathrm{mg} / \mathrm{kg}$ dose levels against a standard drug, glibenclamide. In addition, the structure-activity relationship (SAR) was analyzed to determine the effect of structural modification in chalcones activity. Results: A dose-dependent reduction in postprandial hyperglycemia was observed. The highest reduction in blood glucose level (BGL) was achieved by compound $\mathbf{3}$ at a dose of $100 \mathrm{mg} / \mathrm{kg}$ (39\%). This was found to be even higher than glibenclamide (34.5\%). In the STZinduced diabetic animal model, all test compounds showed comparable efficacy with glibenclamide. The SAR analysis revealed that the incorporation of electron-donating groups at position 5 of the benzaldehyde ring and position 2 of the acetophenone ring is promising to increase the antihyperglycemic activities of chalcones.

Conclusion: The chalcone derivatives considered in this study could be used as potential lead compounds in the discovery of effective drugs to treat diabetes mellitus.

Keywords: antidiabetic, chalcone, diabetes mellitus, structure-activity relationship, streptozotocin, characterization, in vivo

\section{Introduction}

Diabetes mellitus is a metabolic disorder with various etiologies. The disease is marked by chronic hyperglycemia, which is associated with the disturbances of carbohydrate, protein and fat metabolism arising from defects in insulin secretion, action, or both. ${ }^{1}$ The global diabetes prevalence has been steadily increasing over the past three decades. ${ }^{2}$ According to the recent estimation by the International Diabetes Federation (IDF), there were 451 million people with diabetes mellitus in 2017 worldwide and traumatically, this number is expected to rise to 693 million by $2045 .^{3}$

Being a global concern, several pharmacological and non-pharmacological diabetes treatment methods have been reported by different studies. In line with this, some drugs are already approved and commercially available, while some are under clinical trial. ${ }^{4,5}$ In this aspect, chalcones and their derivatives are considered as one of the promising future antidiabetic drugs and have been targeted by many researchers. ${ }^{6,7}$ Chalcones are
Correspondence: Semere Welday Kahssay

Tel +25I-904-296-810

Fax +25I-344-4I6-68I

Email semere0409@gmail.com 


\section{Graphical Abstract}

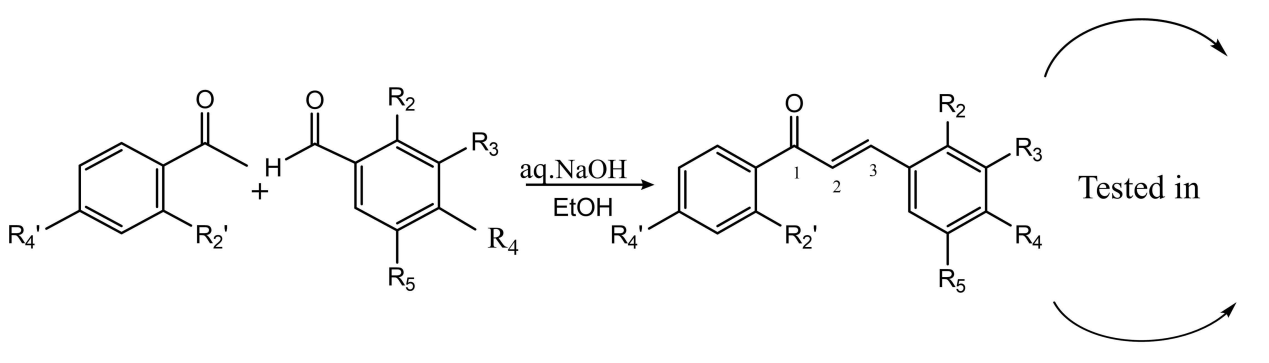

1- $\mathrm{R}_{2},=\mathrm{OH}, \mathrm{R}_{3}=\mathrm{OCH}_{3}, \mathrm{R}_{4}=\mathrm{OH}, \mathrm{R}_{5}=\mathrm{Br}$

2- $\mathrm{R}_{2},=\mathrm{Cl}, \mathrm{R}_{4},=\mathrm{Cl}, \mathrm{R}_{2}=\mathrm{OH}, \mathrm{R}_{3}=\mathrm{OCH}_{3}$

3- $\mathrm{R}_{2}=\mathrm{OH}, \mathrm{R}_{2}=\mathrm{OH}, \mathrm{R}_{3}=\mathrm{OCH}_{3}$

4- $\mathrm{R}_{2},=\mathrm{Cl}, \mathrm{R}_{4},=\mathrm{Cl}, \mathrm{R}_{3}=\mathrm{OCH}_{3}, \mathrm{R}_{4}=\mathrm{OH}, \mathrm{R}_{5}=\mathrm{OCH}_{3}$

5- $\mathrm{R}_{2},=\mathrm{Cl}, \mathrm{R}_{4}=\mathrm{Cl}, \mathrm{R}_{3}=\mathrm{OCH}_{3}, \mathrm{R}_{4}=\mathrm{OH}, \mathrm{R}_{5}=\mathrm{Br}$

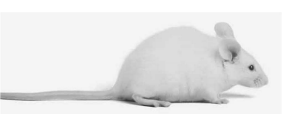

STZ induced diabetic mouse

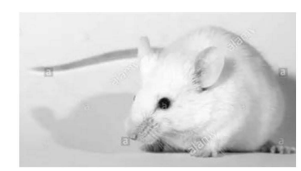

Glucose loaded normal mouse one of the naturally found phytochemicals and are ubiquitous in various plants including the species of Angelica, Glycyrrhiza, Humulus and Scutellaria. Many of these plants are widely used as traditional remedies owing to their diverse pharmacological properties. Chalcones are also abundant in edible plants. Besides, they are taken as precursors during flavonoid biosynthesis. The basic chalcone chromophore contains a 1,3-diphenyl-2-propen-1-one structure where two aromatic rings are joined by a three-carbon unit that has an $\alpha, \beta$-unsaturated carbonyl system. ${ }^{8}$ This chromophore can be found as either trans $(\mathrm{E})$ or cis $(\mathrm{Z})$ isomer, and several studies verified that the $E$ isomer is more stable than the $Z$ isomer. ${ }^{9}$ There are several reactive hydrogens on the basic chalcone structure. This opens opportunities for structural modification and the synthesis of a range of chalcone derivatives. Previous studies have documented that chalcone derivatives show various biological activities including antidiabetic, ${ }^{10-13}$ anti-neoplastic, ${ }^{11,14,15}$ antiinflammatory, ${ }^{16}$ anti-malarial, ${ }^{17}$ antioxidant, ${ }^{16,18}$ anti-gout, ${ }^{19}$ hypolipidemic, ${ }^{13}$ anti-bacterial, ${ }^{16,20}$ and other related activities. $^{9,21-23}$ In particular, studies on the antidiabetic activities of synthetic and natural chalcones (isolated from plants) showed promising activities on different target sites. $^{22}$ With these aspects, metochalcone and sofalcone were recently approved as a choleretic drug and an antiulcer agent, respectively. Furthermore, clinical trials using hesperidin methylchalcone for chronic venous lymphatic insufficiency and hesperidin trimethylchalcone for varicosis led to the relieving of symptoms, reached significant plasma concentrations, and showed good-tolerance making them good drug candidates. ${ }^{21,24}$

Despite the diverse studies conducted to find a longlasting treatment method for diabetes, the signs of progress are challenged by the cost of production, ineffectiveness and affordability. Therefore, there is still a need for discovering and investigating new and effective potential drugs that are easily affordable by diabetic patients. In an effort made to find molecules with promising antidiabetic activities, five chalcone derivatives were synthesized in this study and their relative antidiabetic activities were investigated in vivo. In addition, the structure-activity relationship (SAR) was evaluated to view the association of structural modification and antidiabetic activity.

\section{Materials and Methods}

\section{Chemistry}

All chemicals and reagents used in this research were obtained from commercial suppliers and were of analytical grade. TLC analysis was performed on Silica-gel precoated plate (Merck, Germany). Silica gel packed (100200 mesh size) column chromatography was used for the isolation and purification of the synthesized compounds. IR was recorded on FT-IR spectrometer (SHIMADZU, Japan). ${ }^{1} \mathrm{H}$ NMR, ${ }^{13} \mathrm{C}$ NMR and DEPT-135 spectra were recorded on Bruker $400 \mathrm{MHz}$ and $100 \mathrm{MHz}$ spectrometers (Bruker, Germany). Melting points were determined using the Stuart melting point apparatus (SMP3, VENDOR) and were uncorrected. A glucometer with test strips (i-QARE 
DS-W, Taiwan) was used to measure the blood glucose level of mice.

\section{General Procedure for the Synthesis of Compounds}

The synthesis of all the chalcone derivatives was achieved using Claisen-Schmidt condensation reaction (Scheme 1). ${ }^{24}$ For each reaction, equimolar quantities of benzaldehyde derivatives $(13 \mathrm{mmol})$ and acetophenone derivatives $(13 \mathrm{mmol})$ were dissolved in $65 \mathrm{~mL}$ absolute ethanol in a $250 \mathrm{~mL}$ round-bottom flask equipped with a magnetic stirrer. Then, $60 \%$ aq. $\mathrm{NaOH}(40 \mathrm{~mL})$ was added dropwise and the reaction mixture was stirred at room temperature. The progress of the reaction was monitored by TLC every $2 \mathrm{~h}$ using n-hexane: ethyl acetate (3:1) as mobile phase. After completion of the reaction, the mixture was neutralized with $2 \mathrm{M} \mathrm{HCl}$ and then allowed to cool in an ice bath, whereby a yellow precipitate was formed. The reaction mixture was filtered using a vacuum system, and the resulting solid was then washed with cold water, dried and eluted over silica gel packed column chromatography using the same solvent system to get the target chalcone derivative (Table 1).

\section{Synthesis of (E)-I-(2-Hydroxyphenyl)-} 3-(3-Methoxy-4-Hydroxy-5-Bromophenyl) Prop-2-En-I-One (Compound I)

Yellow solid; yield $75 \%$; m.p. $162-163{ }^{\circ} \mathrm{C}$; $\mathrm{R}_{\mathrm{f}}$ (n-hexane: ethyl acetate 3:1) 0.243; IR ( $\mathrm{KBr})\left(\mathrm{cm}^{-1}\right)$ (Supplementary Figure S1): $3264(\mathrm{O}-\mathrm{H}), 3101$ and $3071(\mathrm{C}-\mathrm{H}), 1675(\mathrm{C}=\mathrm{O})$, $1589(\mathrm{C}=\mathrm{C}), 970(E) ;{ }^{1} \mathrm{H}$ NMR $\left(400 \mathrm{MHz}, \mathrm{CDCl}_{3}\right) \delta(\mathrm{ppm})$ (Supplementary Figure S2A and S2B): 7.94 (dd, J = 8.1, 1.7 $\left.\mathrm{Hz}, 1 \mathrm{H}, 6^{\prime}-\mathrm{H}\right), 7.80(\mathrm{~d}, \mathrm{~J}=15.3 \mathrm{~Hz}, 1 \mathrm{H}, \alpha-\mathrm{H}), 7.66(\mathrm{~d}, \mathrm{~J}=$ $1.8 \mathrm{~Hz}, 1 \mathrm{H}, 6-\mathrm{H}), 7.52$ (ddd, J = 8.6, 7.2, $2.1 \mathrm{~Hz}, 1 \mathrm{H}, 4^{\prime}-\mathrm{H}$ ), 7.38-7.28 (m, 2H, 2-H, $\beta-\mathrm{H}), 7.11-7.02$ (m, 1H, 3'-H), 6.97 (ddd, J = 8.2, 7.1, $\left.1.2 \mathrm{~Hz}, 1 \mathrm{H}, 5^{\prime}-\mathrm{H}\right), 6.65$ (s, 1H, 2'-OH), $4.01(\mathrm{~s}, 1 \mathrm{H}, 4-\mathrm{OH}), 4.00\left(\mathrm{~s}, 3 \mathrm{H}, \mathrm{OC}_{3}\right)$;<smiles>[R]c1ccc(C(C)=O)c([R2])c1</smiles>

Table I Structures of the Synthesized Chalcone Derivatives (I-5)

\begin{tabular}{|l|c|c|c|c|c|c|}
\hline Compounds & $\mathbf{R}_{\mathbf{1}}$ & $\mathbf{R}_{\mathbf{2}}$ & $\mathbf{R}_{\mathbf{3}}$ & $\mathbf{R}_{\mathbf{4}}$ & $\mathbf{R}_{\mathbf{l}}$ & $\mathbf{R}_{\mathbf{2}}$ \\
\hline $\mathrm{I}$ & $\mathrm{H}$ & $\mathrm{OCH}_{3}$ & $\mathrm{OH}$ & $\mathrm{Br}$ & $\mathrm{H}$ & $\mathrm{OH}$ \\
2 & $\mathrm{OH}$ & $\mathrm{OCH}_{3}$ & $\mathrm{H}$ & $\mathrm{H}$ & $\mathrm{Cl}$ & $\mathrm{Cl}$ \\
3 & $\mathrm{OH}$ & $\mathrm{OCH}_{3}$ & $\mathrm{H}$ & $\mathrm{H}$ & $\mathrm{H}$ & $\mathrm{OH}$ \\
4 & $\mathrm{H}$ & $\mathrm{OCH}_{3}$ & $\mathrm{OH}$ & $\mathrm{OCH}_{3}$ & $\mathrm{Cl}$ & $\mathrm{Cl}$ \\
5 & $\mathrm{H}$ & $\mathrm{OCH}_{3}$ & $\mathrm{OH}$ & $\mathrm{Br}$ & $\mathrm{Cl}$ & $\mathrm{Cl}$ \\
\hline
\end{tabular}

Synthesis of (E)-I-(2,4-Dichlorophenyl)3-(2-Hydroxy-3-Methoxyphenyl)prop2-En-I-One (Compound 2)

Light yellow solid; yield 78\%; m.p. $118-119^{\circ} \mathrm{C}$; $\mathrm{R}_{\mathrm{f}}(\mathrm{n}$-hexane:ethyl acetate $3: 1) \quad 0.378 ; \quad$ IR $\quad(\mathrm{KBr}) \quad\left(\mathrm{cm}^{-1}\right)$ (Supplementary Figure S3): $3416(\mathrm{O}-\mathrm{H}), 3141$ and 3085 $(\mathrm{C}-\mathrm{H}), 1636(\mathrm{C}=\mathrm{O}), 1599(\mathrm{C}=\mathrm{C}), 981(E) ;{ }^{1} \mathrm{H}$ NMR (400 $\left.\mathrm{MHz}, \mathrm{CDCl}_{3}\right) \delta(\mathrm{ppm})$ (Supplementary Figure S4A and S4B): $7.76(\mathrm{~d}, \mathrm{~J}=16.2 \mathrm{~Hz}, 1 \mathrm{H}, \alpha-\mathrm{H}), 7.48(\mathrm{~d}, \mathrm{~J}=1.9 \mathrm{~Hz}$, $\left.1 \mathrm{H}, 3^{\prime}-\mathrm{H}\right), 7.45\left(\mathrm{~d}, \mathrm{~J}=8.2 \mathrm{~Hz}, 1 \mathrm{H}, 6^{\prime}-\mathrm{H}\right), 7.35(\mathrm{dd}, \mathrm{J}=8.2$, $\left.1.9 \mathrm{~Hz}, 1 \mathrm{H}, 5^{\prime}-\mathrm{H}\right), 7.29$ (d, J = 16.2 Hz, 1H, $\left.\beta-\mathrm{H}\right), 7.14$ (dd, $\mathrm{J}=7.4,1.9 \mathrm{~Hz}, 1 \mathrm{H}, 6-\mathrm{H}), 6.93-6.85(\mathrm{~m}, 2 \mathrm{H}, 5.4-\mathrm{H}), 6.32$ (s, $1 \mathrm{H}, \mathrm{OH}), 3.92\left(\mathrm{~s}, 3 \mathrm{H}, \mathrm{OCH}_{3}\right) ;{ }^{13} \mathrm{C} \mathrm{NMR}(100 \mathrm{MHz}$, $\left.\mathrm{CDCl}_{3}\right) \delta(\mathrm{ppm})$ (Supplementary Figure S5): $193.27(\mathrm{C}=\mathrm{O})$, 146.90 (C-2), 145.92 (C-3), 141.90 (C- $\beta$ ), 137.67 (C-2'), 136.64 (C-1'), 132.40 (C-4'), 130.43 (C-6'), 130.15 (C-3'), 127.17 (C-5'), 126.85 (C-5), $121.11(\mathrm{C}-\alpha), 120.66$ (C-1), 119.86 (C-6), 112.51 (C-4), $56.24\left(\mathrm{OCH}_{3}\right)$; DEPT-135 $\delta$ (ppm) (Supplementary Figure S6): $141.90(\mathrm{CH}), 130.43$ $(\mathrm{CH}), 130.15(\mathrm{CH}), 127.17(\mathrm{CH}), 126.85(\mathrm{CH}), 121.11$ $(\mathrm{CH}), 119.86(\mathrm{CH}), 112.51(\mathrm{CH})$, and $56.24\left(\mathrm{O}-\mathrm{CH}_{3}\right)$.

Synthesis of (E)-I-(2-Hydroxyphenyl)3-(2-Hydroxy-3-Methoxyphenyl)

\section{Prop-2-En-I-One (Compound 3)}

Dark yellow solid; yield 81.5\%; m.p. $176.5-177.5{ }^{\circ} \mathrm{C}$; $\mathrm{R}_{\mathrm{f}}$ (n-hexane:ethyl acetate 3:1) 0.350; IR ( $\mathrm{KBr})\left(\mathrm{cm}^{-1}\right)$ (Supplementary Figure S7): $3334(\mathrm{O}-\mathrm{H}), 1629(\mathrm{C}=\mathrm{O})$,

Scheme I Reagents and conditions: $60 \%$ aq. $\mathrm{NaOH}$, Ethanol, RT.<smiles>[R1]c1ccc(C(=O)/C=C/c2cc([R5])c([R4])c([R])c2[R2])c([R2])c1</smiles> 
$1605(\mathrm{C}=\mathrm{C}), 970(E) ;{ }^{1} \mathrm{H}$ NMR (400 MHz, $\left.\mathrm{CDCl}_{3}\right) \delta$ (ppm) (Supplementary Figure S8A and S8B): 8.16 (d, $\mathrm{J}=15.6 \mathrm{~Hz}, 1 \mathrm{H}, \alpha-\mathrm{H}), 7.97(\mathrm{dd}, \mathrm{J}=8.0,1.2 \mathrm{~Hz}, 1 \mathrm{H}$, $\left.6^{\prime}-\mathrm{H}\right), 7.95(\mathrm{~d}, \mathrm{~J}=15.5 \mathrm{~Hz}, 1 \mathrm{H}, \beta-\mathrm{H}), 7.54-7.49(\mathrm{~m}, 1 \mathrm{H}$, $\left.4^{\prime}-\mathrm{H}\right), 7.23-7.20\left(\mathrm{~m}, 1 \mathrm{H}, 5^{\prime}-\mathrm{H}\right), 7.05$ (dd, J = 8.2, $1.4 \mathrm{~Hz}$, 1H, 6-H), 6.99-6.89 (m, 3H, 3',4,5-H), 6.41 (s, 1H, 2'$\mathrm{OH}), 3.97$ (s, 3H, $\left.\mathrm{OCH}_{3}\right), 3.94(\mathrm{~s}, 1 \mathrm{H}, 2-\mathrm{OH}) ;{ }^{13} \mathrm{C} \mathrm{NMR}$ $\left(100 \mathrm{MHz}, \mathrm{CDCl}_{3}\right) \delta(\mathrm{ppm})$ (Supplementary Figure S9): $194.44(\mathrm{C}=\mathrm{O}), 163.58\left(\mathrm{C}-2^{\prime}\right), 146.15(\mathrm{C}-2), 140.92(\mathrm{C}-\beta)$, 137.99 (C-3), 136.16 (C-4'), 129.83 (C-6'), 122.22 (C-5), $121.63\left(\mathrm{C}^{\prime} 5^{\prime}\right), 121.05$ (C-1'), 120.24 (C-1), 119.82 (C- $\left.\alpha\right)$, 118.77 (C-6), 118.52 (C-3'), 112.31 (C-4), $56.28\left(\mathrm{OCH}_{3}\right)$; DEPT-135 $\delta(\mathrm{ppm})$ (Supplementary Figure S10): 140.92 $(\mathrm{CH}), 136.16(\mathrm{CH}), 129.83(\mathrm{CH}), 122.22(\mathrm{CH}), 121.63$ $(\mathrm{CH}), 119.82(\mathrm{CH}), 118.77(\mathrm{CH}), 118.52(\mathrm{CH}), 112.31$ $(\mathrm{CH}), 56.28\left(\mathrm{O}-\mathrm{CH}_{3}\right)$.

\section{Synthesis of (E)-I-(2,4-Dichlorophenyl)-} 3-(4-Hydroxy-3,5-Dimethoxyphenyl) Prop-2-En-I-One (Compound 4)

Yellow solid; yield 73.6\%; m.p. 93-94 ${ }^{\circ} \mathrm{C}$; $\mathrm{R}_{\mathrm{f}}$ (n-hexane: ethyl acetate $3: 1)$ 0.148; IR $(\mathrm{KBr})\left(\mathrm{cm}^{-1}\right)$ (Supplementary Figure S11): 3317 (O-H), 3117 and 3073 (C-H), 1651 $(\mathrm{C}=\mathrm{O}), 1602 \quad(\mathrm{C}=\mathrm{C}), 976(\mathrm{E}) ;{ }^{1} \mathrm{H}$ NMR $(400 \mathrm{MHz}$, $\left.\mathrm{CDCl}_{3}\right) \quad \delta(\mathrm{ppm})$ (Supplementary Figure $\mathrm{S} 12 \mathrm{~A}$ and S12B): $7.47\left(\mathrm{~d}, \mathrm{~J}=1.9 \mathrm{~Hz}, 1 \mathrm{H}, 3^{\prime}-\mathrm{H}\right), 7.41(\mathrm{~d}, \mathrm{~J}=8.2$ $\left.\mathrm{Hz}, 1 \mathrm{H}, 6^{\prime}-\mathrm{H}\right), 7.36-7.30\left(\mathrm{~m}, 2 \mathrm{H}, \alpha-\mathrm{H}, 5^{\prime}-\mathrm{H}\right), 6.95$ (d, J = $16.0 \mathrm{~Hz}, 1 \mathrm{H}, \beta-\mathrm{H}), 6.80$ (s, 2H, 2.6-H), 3.95 (s, 1H, OH), $3.91\left(\mathrm{~s}, 6 \mathrm{H}, 3.5-\mathrm{OCH}_{3}\right) ;{ }^{13} \mathrm{C} \mathrm{NMR}\left(100 \mathrm{MHz}, \mathrm{CDCl}_{3}\right) \delta$ (ppm) (Supplementary Figure S13): $192.74(\mathrm{C}=\mathrm{O}), 147.56$ (C- $\beta$ ), 147.34 (C-3, C-5), 138.08 (C-2'), 137.62 (C-4), $136.61\left(\mathrm{C}-1^{\prime}\right), \quad 132.22 \quad\left(\mathrm{C}-4^{\prime}\right), \quad 130.24 \quad\left(\mathrm{C}-6^{\prime}\right), \quad 130.11$ $\left(\mathrm{C}-3^{\prime}\right), 127.25\left(\mathrm{C}-5^{\prime}\right), 125.66$ (C-1), 124.02 (C- $\left.\alpha\right), 105.75$ $(\mathrm{C}-2, \quad \mathrm{C}-6), \quad 56.38 \quad\left(\mathrm{OCH}_{3}\right) ; \quad$ DEPT-135 $\delta \quad(\mathrm{ppm})$ (Supplementary Figure S14): $147.56(\mathrm{CH}), 130.24(\mathrm{CH})$, $130.11(\mathrm{CH}), 127.25(\mathrm{CH}), 124.02(\mathrm{CH}), 105.75(\mathrm{CH})$, $56.38\left(\mathrm{O}-\mathrm{CH}_{3}\right)$.

\section{Synthesis of (E)-I-(2,4-Dichlorophenyl)-} 3-(5-Bromo-4-Hydroxy3-Methoxyphenyl) Prop-2-En-I-One (Compound 5)

Yellow solid; yield $71 \%$; m.p. $145-146{ }^{\circ} \mathrm{C}$; $\mathrm{R}_{\mathrm{f}}$ (n-hexane: ethyl acetate 3:1) 0.256; IR (KBr) $\left(\mathrm{cm}^{-1}\right)$ (Supplementary Figure S15): $3322(\mathrm{O}-\mathrm{H}), 3140$ and $3092(\mathrm{C}-\mathrm{H}), 1656$ $(\mathrm{C}=\mathrm{O}), 1607 \quad(\mathrm{C}=\mathrm{C}), 972 \quad(\mathrm{E}) ;{ }^{1} \mathrm{H}$ NMR $(400 \mathrm{MHz}$,
$\left.\mathrm{CDCl}_{3}\right) \quad \delta(\mathrm{ppm})$ (Supplementary Figure S16A and S16B): $7.47\left(\mathrm{~d}, \mathrm{~J}=1.9 \mathrm{~Hz}, 1 \mathrm{H}, 3^{\prime}-\mathrm{H}\right), 7.42(\mathrm{~d}, \mathrm{~J}=8.2$ $\left.\mathrm{Hz}, 1 \mathrm{H}, 6^{\prime}-\mathrm{H}\right), 7.36$ (d, J = 2.0 Hz, 1H, 6-H), 7.34-7.28 (m, $\left.2 \mathrm{H}, 5^{\prime}-\mathrm{H}, \alpha-\mathrm{H}\right), 7.01$ (d, J = 1.9 Hz, 1H, 2-H), 6.97 (d, J = $16.0 \mathrm{~Hz}, 1 \mathrm{H}, \beta-\mathrm{H}), 6.45$ (s, 1H, OH), 3.94 (s, 3H, OC $\left.\mathrm{H}_{3}\right)$; ${ }^{13} \mathrm{C}$ NMR $\left(100 \mathrm{MHz}, \mathrm{CDCl}_{3}\right) \delta$ (ppm) (Supplementary Figure S17): $192.40(\mathrm{C}=\mathrm{O}), 147.44(\mathrm{C}-3), 145.87\left(\mathrm{C}-2^{\prime}\right)$, 145.50 (C- $\beta), 137.38$ (C-4), $136.89\left(\mathrm{C}-1^{\prime}\right), 132.26\left(\mathrm{C}-4^{\prime}\right)$, 130.33 (C-6'), 130.17 (C-3'), 127.42 (C-1), 127.32 (C-5'), 126.51 (C-6), 124.79 (C- $\alpha$ ), 109.08 (C-2), 108.75 (C-5), $56.49\left(\mathrm{OCH}_{3}\right)$; DEPT-135 $\delta$ (ppm) (Supplementary Figure $\underline{\mathrm{S} 18)} ; 145.50(\mathrm{CH}), 130.33(\mathrm{CH}), 130.17(\mathrm{CH}), 127.32$ $(\mathrm{CH}), \quad 126.51 \quad(\mathrm{CH}), \quad 124.79 \quad(\mathrm{CH}), \quad 109.08 \quad(\mathrm{CH})$, $56.49(\mathrm{CH})$.

\section{Biological Activities Experimental Animals}

Swiss albino mice weighing $25 \pm 3 \mathrm{~g}$ and of age 6-8 weeks were obtained from the Department of Pharmacology, School of Pharmacy, College of Health Sciences, Mekelle University. The animals were housed in standard cages and maintained on a standard pelleted diet and water. After randomization into various groups and before initiation of the experiment, the mice were acclimatized to the animal house conditions (room temperature of $22 \pm 3{ }^{\circ} \mathrm{C}$, relative humidity of $50-60 \%$, and $12 \mathrm{~h}$ light and $12 \mathrm{~h}$ dark cycle) for 7 days. Ethical clearance was obtained from Mekelle University, College of Health Sciences ethics committee. Besides, the guide for the care and use of laboratory animals was followed for the welfare and treatment of the laboratory animals. $^{25}$

\section{Induction of Experimental Diabetes}

Experimental mice were made diabetic by a single intraperitoneal injection of STZ. STZ was dissolved in $0.1 \mathrm{M}$ citrate buffer ( $\mathrm{pH} 4.5)$ and a calculated amount of freshly prepared solution was injected into overnight fasted animals at a dose of $60 \mathrm{mg} / \mathrm{kg}$ body weight intraperitoneally. ${ }^{26}$ The level of fasting blood glucose (FBG) of each animal was checked 72 hrs later using a glucometer by taking blood samples from the tail vein of the mice. The blood glucose level of each mouse was measured three to four times and those showing average blood glucose levels above $200 \mathrm{mg} / \mathrm{dL}$ were finally included in the experiment and named as STZ-induced diabetic mice. ${ }^{27,28}$ 


\section{Biological Assays}

In vivo Acute Oral Toxicity Test

Oral acute toxicity of the test compounds was investigated using female Swiss albino mice. The mice were fasted for 4 hrs before administering test compounds. After checking the solubility profile of the test compounds at different dose levels, 5\% DMSO was used as a vehicle which was prepared using distilled water. The test compounds were given orally in a sequential dose starting at a dose of $10 \mathrm{mg} / \mathrm{kg}$. After observing for signs of toxicity for $48 \mathrm{hrs}$ with special attention to the first $4 \mathrm{hrs}$, the next dose of $50 \mathrm{mg} / \mathrm{kg}$ was administered. Dosing continued up to $500 \mathrm{mg} / \mathrm{kg}$, and their survival was followed up to 14 days. Acute toxicity signs like lacrimation, hair erection, blinking, urination, muscle weakness, sedation and convulsion, reduction in motor activity, diarrhea, coma and death were checked in test mice. ${ }^{29}$

Oral Glucose Tolerance Test (OGTT) in Normal Mice OGTT was performed using male Swiss albino mice. After overnight fasting (16 hrs), BGL of each mouse was checked, and those mice with blood glucose levels between 60 and $90 \mathrm{mg} / \mathrm{dL}$ were divided into twelve groups of six mice each. Mice of experimental groups took the solution of the synthetic compounds orally dissolved in $5 \%$ DMSO at a dose of $50 \mathrm{mg} / \mathrm{kg}$ and $100 \mathrm{mg} / \mathrm{kg}$ body weight. Animals of the negative control group took an equal amount of DMSO whereas animals of the positive control group took glibenclamide $10 \mathrm{mg} / \mathrm{kg}$ body weight orally. A glucose load ( $2.5 \mathrm{~g} / \mathrm{kg}$ body weight) was given to each animal orally exactly after 30 minutes postadministration of the test sample/vehicle. ${ }^{12}$ The blood glucose profile of each mouse was again determined at 0 , 30, 60, 90 and 120 minutes post-administration of glucose using a glucometer. The BGL of each mouse was measured three to four times and the average value was taken. Food but not water was removed from cages during the experimentation. ${ }^{12,30}$

\section{Dose Optimization}

Screening of the test compounds for hypoglycaemic activity was performed at two dose levels $(50 \mathrm{mg} / \mathrm{kg}$ and $100 \mathrm{mg} / \mathrm{kg}$ body weight) in normal healthy mice with the OGTT. A dose that improved glucose tolerance analogous to the standard drug (glibenclamide) was selected for further studies.

\section{In vivo Antidiabetic Activity}

STZ-induced diabetic mice were weighed and randomly divided into seven groups of six mice per group per cage. Group 1 received vehicle (5\% DMSO), serving as a diabetic control group. Group 2 received the standard drug, glibenclamide, serving as a positive control group. Groups 3-7 were treated with synthesized compounds (15) dissolved in DMSO, respectively.

The mice were made to fast overnight and the fasting serum glucose, day 0 , levels were calculated. The individual test compounds were administered at a dose of $100 \mathrm{mg} / \mathrm{kg}$ per os daily for 21 days at a fixed time. The negative control group received the same volume of the vehicle, whereas the positive control group received glibenclamide at a dose of $10 \mathrm{mg} / \mathrm{kg}$ body weight.

During the study, blood samples were taken from all mice on days $0,7,14$ and 21, and percentage reduction in FBG was calculated. Blood samples were taken three to four times from the tail vein of each mouse on each day and the average value was determined. Glibenclamide was used as a reference drug in the determination of the in vivo antidiabetic activity of the synthesized compounds.

\section{Data and Statistical Analysis}

Measurements were made in quintuplicate $(n=6)$ unless otherwise mentioned and data were expressed as mean \pm SEM. One-way analysis of variance (ANOVA) followed by Tukey Post-Hoc test was used to determine the significant differences between groups. Differences were considered to be significant at $p \leq 0.05$. All the statistical analysis was conducted using SPSS-software (version 22). GraphPad prism version 9.1.2 was used for drawing graphs, and MS Excel 2016 was used for calculating AUC.

\section{Results and Discussion Chemistry}

Scheme 1 shows the general synthesis procedure of the target chalcone derivatives. Briefly, compounds 1-5 were synthesized through base-catalyzed Claisen-Schmidt condensations using acetophenones substituted at position 2 or 4 or 2 and 4 and appropriately substituted benzaldehyde derivative. The identities of the compounds were confirmed using IR and several NMR spectral data that agreed with the proposed structures (Supplementary data). 


\section{Biological Activities Bioassay Tests}

The acute oral toxicity test was conducted to assess the acute lethal, physical and behavioral changes in response to the oral administration of the newly synthesized compounds. The chalcones were administered in a sequential dose starting from 10 to $500 \mathrm{mg} / \mathrm{kg}$, and the weight of each mouse was recorded before and after receiving treatment. Survival was followed up to 14 days, and no mice showed signs of toxicity. Besides, no death was recorded during the follow-up period. Interestingly, there was no significant difference in the weight of the mice before and after treatments, which signifies that the median lethal dose $\left(\mathrm{LD}_{50}\right)$ of each of the test compounds was greater than $500 \mathrm{mg} / \mathrm{kg}$.

The blood glucose-lowering effect of each chalcone derivative was tested at 50 and $100 \mathrm{mg} / \mathrm{kg}$ dose levels, and their effect on postprandial BGL in normal mice is shown in Table 2. The concentration of blood glucose in mice was measured at six time points, including immediately before administration of the test compounds ( -30 $\mathrm{min})$, immediately before glucose load ( $0 \mathrm{~min})$ and at 30 , 60,90 and 120 min post-administration of glucose. The area under the curve (AUC) of each group was determined by plotting BGL against time, and it was used to determine the overall percentage of lowering in postprandial (postglucose load) hyperglycemia. The results of AUC were used to compare the test compounds with each other, with the positive control group and the vehicle-treated group. All the test compounds showed significant changes in BGL at both dose levels compared to the negative control group (Figure 1A and B) (Table 2). In all the groups, the peak blood glucose level was seen 30 min postadministration where glibenclamide and the test compounds started to show a significant change in BGL. The highest percent reduction (39\%) was seen in mice treated with compound 3 at a dose of $100 \mathrm{mg} / \mathrm{kg}$. This value was even higher than the percent reduction achieved by glibenclamide (34.5\%). Mice treated with compounds 1, 2, 4 and 5 showed 25.2, 15.4, 23.6 and 10.7\% reductions at a dose of $50 \mathrm{mg} / \mathrm{kg}$, and $34.3,22.5,32.5$, and $25.4 \%$ reductions at a dose of $100 \mathrm{mg} / \mathrm{kg}$, respectively (Tables 2 and 3).

It is evident from Table 3 that the improvements in postprandial hyperglycemia were found to be dosedependent in all the test compounds. The highest dosedependent effect was observed for compounds 3 and $\mathbf{4}$, while the lowest dose-dependent effect was observed for compound 2 .

Table 3 presents the percent reduction in postprandial hyperglycemia of the test compounds at each time point. Once again, compound 3 showed the highest reduction at a dose of $100 \mathrm{mg} / \mathrm{kg}$ at each time point, while compounds $\mathbf{1}$ and $\mathbf{4}$ showed a reduction comparable to glibenclamide $(10 \mathrm{mg} / \mathrm{kg})$. In contrast to glibenclamide, which showed its peak reduction (39.74\%) at 120 min post-administration of glucose, all the test compounds showed their highest reduction in BGL at 60 min post-administration of glucose. These findings indicate that the compounds could be primary choices when there is a need for rapid reduction in BGL.

The comparison of test compounds revealed that the postprandial hyperglycemia reductions of compounds $\mathbf{1 ,} \mathbf{3}$, and 4 were significantly different from those of compounds $\mathbf{2}$ and $\mathbf{5}$ but not with each other at similar dose levels. At a dose of $100 \mathrm{mg} / \mathrm{kg}$, the test compounds showed significant improvements in postprandial glucose tolerance comparable to glibenclamide and, hence, were taken for further antidiabetic activity study using STZinduced diabetic mice.

The relative long-term effect of the chalcone derivatives on BGL was tested in vivo using STZ-induced diabetic mice. The test compounds and the standard drug were administered daily for 21 days at a fixed time after induction of diabetes. BGL was measured on days $0,7,14$, and 21 at the same time and the results are shown in Table 4. Both glibenclamide and the test compounds showed significant reductions in BGL on days 7, 14 and 21 compared to the diabetic control group. On each day, all test compounds showed a comparable reduction in fasting BGL compared to the standard drug (glibenclamide), and the highest effect was seen on day 21. By comparison, compound $\mathbf{3}$ was found to show the highest antidiabetic activity (56.6\% reduction) followed by 1 (51.3\% reductio). Furthermore, compounds $\mathbf{2}, \mathbf{4}$ and $\mathbf{5}$ showed significant antidiabetic activities after 21 days of treatment and showed fasting BGL reductions of 46.6, 51.1 , and $50.8 \%$, respectively. Glibenclamide $(10 \mathrm{mg} / \mathrm{kg})$ showed a $57.2 \%$ reduction, and this value was not significantly different from those of the test compound $(100 \mathrm{mg} /$ $\mathrm{kg}$ ). The test compounds also did not show significant variation with each other in reducing fasting BGL in STZinduced diabetic mice.

The effects of the synthesized chalcone derivatives on the bodyweight of STZ-induced diabetic mice were also 


\begin{tabular}{|c|c|c|c|c|c|c|c|c|c|c|c|c|}
\hline 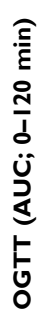 & 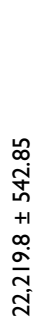 & 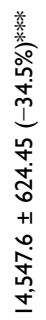 & 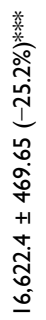 & 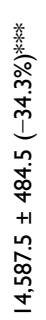 & 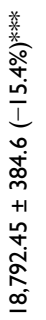 & 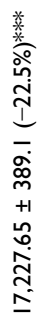 & 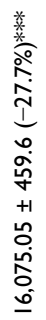 & 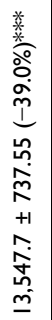 & 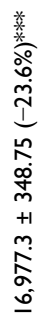 & 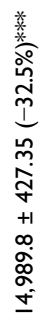 & 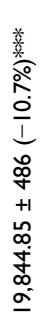 & 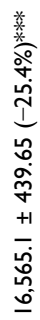 \\
\hline
\end{tabular}

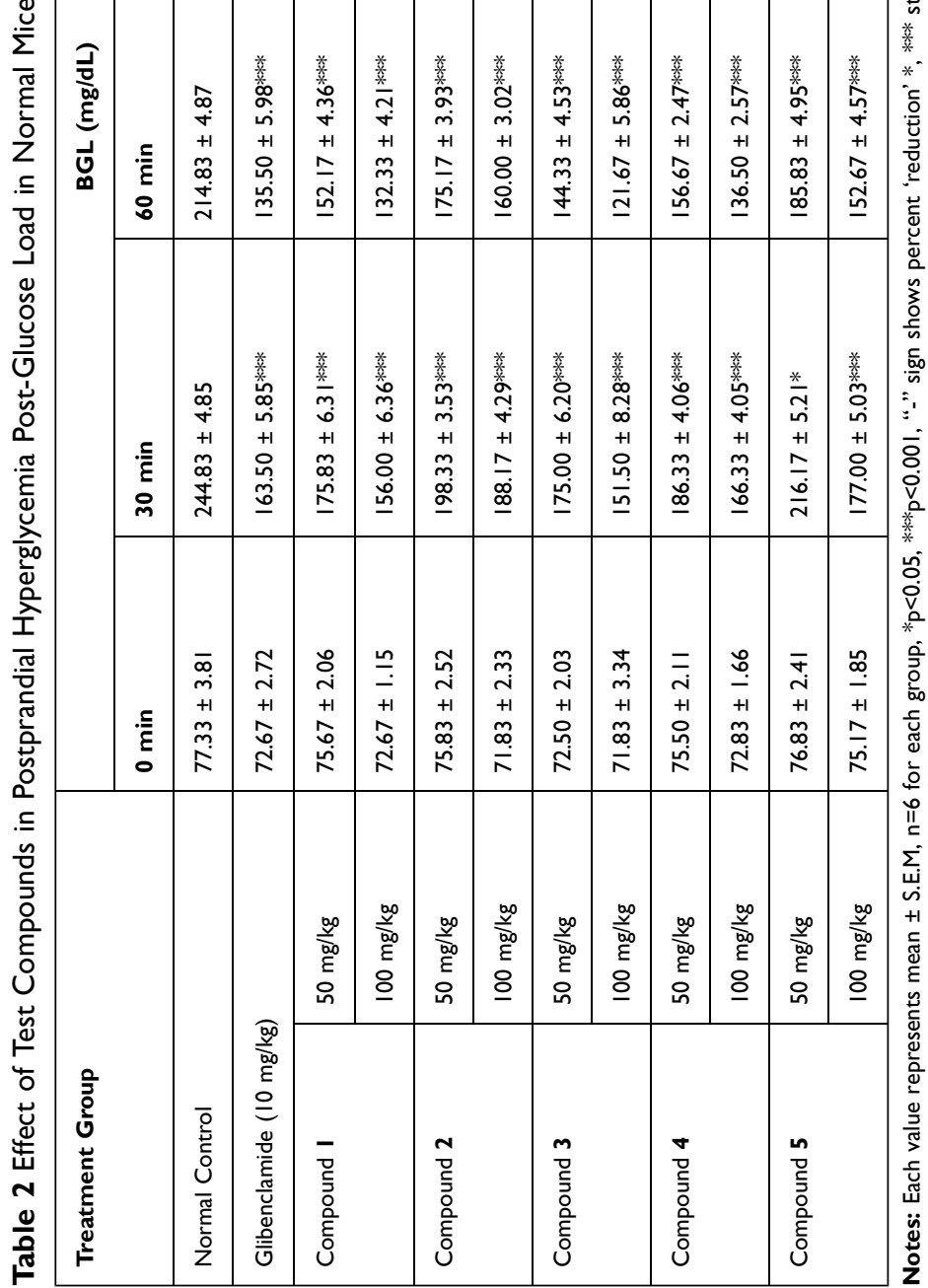



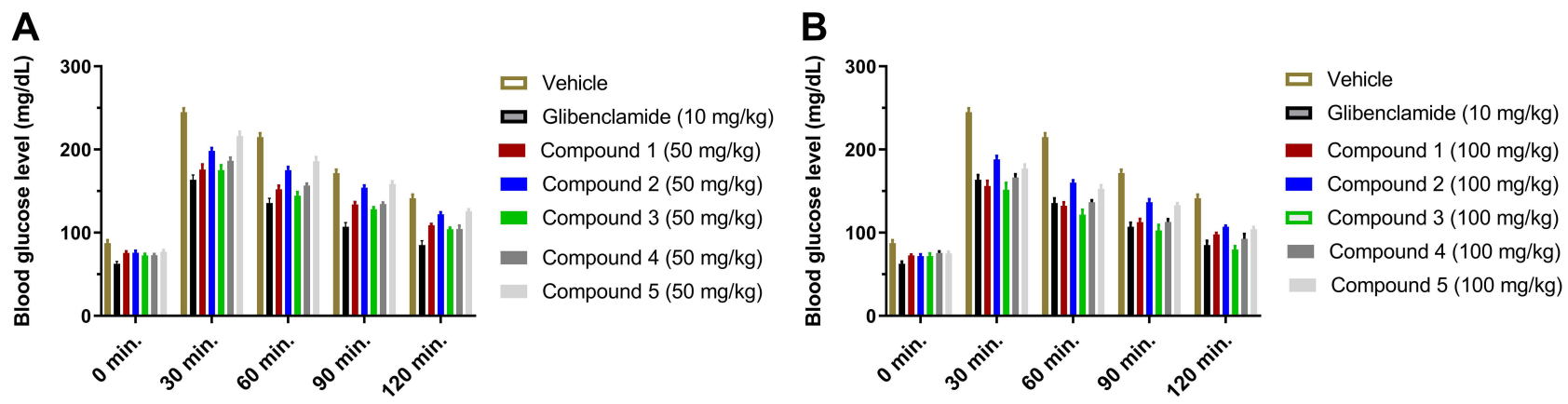

Figure I (A) Comparative inhibitory effect of the synthesized compounds in postprandial hyperglycemia post-glucose load in normal mice at a dose of $50 \mathrm{mg} / \mathrm{kg}$. (B) Comparative inhibitory effect of the synthesized compounds in postprandial hyperglycemia post-glucose load in normal mice at a dose of $100 \mathrm{mg} / \mathrm{kg}$.

evaluated and the results are given in Table 5. Daily oral administration of test compounds for 21 days at $100 \mathrm{mg} / \mathrm{kg}$ dose showed improvements in body weight. Compared to the diabetic control group that showed significant weight reduction $(10.2 \%)$, glibenclamide increased the bodyweight of the mice by about $11 \%$, whereas compounds $\mathbf{1}$, 2, 3, 4 and 5 increased body weight by 6.1, 3, 10.3, 6 and $8.1 \%$, respectively. The change in body weight caused by each of the rest test compounds was not significantly different from that of glibenclamide. Compound $\mathbf{2}$ was an exception in this regard since it showed a significant body weight reduction (4.8\%). Likewise, compound 3 showed a weight gain by $0.3 \%$.

\section{SAR of the Synthesized Compounds for Their Antidiabetic Activity}

The structural variation of the synthesized chalcones brought significant variation in their antidiabetic activities (Figure 2, Table 1). Compounds 2 and 3, which differ only on the type of substituents at positions $2^{\prime}$ and 4 ', showed a significant difference in reducing postprandial hyperglycemia. The former showed 15.4 and $22.5 \%$, while the latter showed 27.7 and $39 \%$ reduction of postprandial hyperglycemia at doses of $50 \mathrm{mg} / \mathrm{kg}$ and $100 \mathrm{mg} / \mathrm{kg}$, respectively. These findings indicated that the presence of a hydroxyl group at $2^{\prime}$ position improved glucose tolerance. This justification could also be applicable to the

Table 3 Effect of Test Compounds at Two Dose Levels and Each Time Points in Reducing Postprandial Hyperglycemia

\begin{tabular}{|c|c|c|c|c|c|c|c|}
\hline \multicolumn{2}{|c|}{ Treatment Groups } & \multicolumn{5}{|c|}{ Percent Reduction in BGL } & \multirow[t]{2}{*}{ OGTT (AUC; 0-1 $20 \mathrm{~min}$ ) } \\
\hline & & 0 min. & $30 \mathrm{~min}$. & $60 \mathrm{~min}$. & $90 \mathrm{~min}$. & $120 \mathrm{~min}$. & \\
\hline \multicolumn{2}{|c|}{ Glibenclamide (10 mg/kg) } & 6.0 & 33.22 & 36.93 & 37.67 & 39.74 & 34.5 \\
\hline \multirow[t]{2}{*}{ Compound I } & $50 \mathrm{mg} / \mathrm{kg}$ & 2.1 & 28.18 & 29.17 & 22.04 & 22.99 & 25.2 \\
\hline & $100 \mathrm{mg} / \mathrm{kg}$ & 6.0 & 36.28 & $38.40^{\mathrm{b} *}$ & $34.37^{\mathrm{b} *}$ & 30.78 & $34.3^{\mathrm{b} * *}$ \\
\hline \multirow[t]{2}{*}{ Compound 2} & $50 \mathrm{mg} / \mathrm{kg}$ & 1.9 & 18.99 & 18.46 & 10.29 & 13.68 & 15.4 \\
\hline & $100 \mathrm{mg} / \mathrm{kg}$ & 7.1 & 23.14 & 25.52 & $20.39^{\mathrm{b} *}$ & $24.29^{\mathrm{b} *}$ & $22.5^{\mathrm{b} *}$ \\
\hline \multirow[t]{2}{*}{ Compound 3} & $50 \mathrm{mg} / \mathrm{kg}$ & 6.2 & 28.52 & 32.82 & 25.34 & 26.29 & 27.7 \\
\hline & $100 \mathrm{mg} / \mathrm{kg}$ & 7.1 & $38.12^{\mathrm{b} *}$ & $43.36^{\mathrm{b} *}$ & $40.19^{\mathrm{b} * *}$ & $43.63^{\mathrm{b} * * *}$ & $39^{\mathrm{b} * * *}$ \\
\hline \multirow[t]{2}{*}{ Compound 4} & $50 \mathrm{mg} / \mathrm{kg}$ & 2.4 & 23.89 & 27.07 & 21.75 & 26.18 & 23.6 \\
\hline & $100 \mathrm{mg} / \mathrm{kg}$ & 5.8 & 32.06 & $36.46^{\mathrm{b} *}$ & $34.28^{\mathrm{b}} *$ & 34.55 & $32.5^{\mathrm{b} * *}$ \\
\hline \multirow[t]{2}{*}{ Compound $\mathbf{5}$} & $50 \mathrm{mg} / \mathrm{kg}$ & 0.6 & 11.71 & 13.50 & 7.77 & 11.20 & 10.7 \\
\hline & $100 \mathrm{mg} / \mathrm{kg}$ & 2.8 & $27.70^{\mathrm{b} * * *}$ & $28.93^{\mathrm{b} * * *}$ & $22.62^{\mathrm{b} * *}$ & $26.29^{\mathrm{b} * *}$ & $25.4^{\mathrm{b} * * *}$ \\
\hline
\end{tabular}

Notes: ${ }^{b}$ Comparison of each compound at different dose levels, $\mathrm{n}=6, * \mathrm{P}<0.05, * * \mathrm{p}<0.01$, $* * * \mathrm{P}<0.001$. 
Table 4 Effect of Synthesized Compounds (Each $100 \mathrm{Mg} / \mathrm{Kg}$ ) on Fasting Blood Glucose Level of STZ-Induced Diabetic Mice

\begin{tabular}{|c|c|c|c|c|c|}
\hline \multirow[t]{2}{*}{ Treatment Groups } & \multicolumn{4}{|c|}{ Fasting Blood Glucose Level (mg/dL) (Mean \pm SEM) } & \multirow{2}{*}{$\begin{array}{c}\text { Percent } \\
\text { Change in } \\
\text { BGL Between } \\
\text { Day } 0 \text { and 2I }\end{array}$} \\
\hline & Day 0 & Day 7 & Day I4 & Day 21 & \\
\hline Diabetic control & $261.67 \pm 10.13$ & $287.33 \pm 10.66$ & $306.5 \pm 9.74$ & $323.83 \pm 6.31$ & $+23.8 \%$ \\
\hline Glibenclamide (10 mg/kg) & $267.67 \pm 8.38$ & $203.83 \pm 5.56(-29.1 \%)^{*}$ & $151.0 \pm 3.10(-50.7 \%)^{*}$ & $\mathrm{I} \mid \mathrm{l} .67 \pm \mathrm{I} .86(-64.6 \%)^{*}$ & $-57.2 \%$ \\
\hline Compound I & $269.83 \pm 11.17$ & $210.67 \pm 8.45(-26.7 \%)^{*}$ & $165.5 \pm 4.68(-46.0 \%)^{*}$ & $|3| .33 \pm 2.58(-59.4 \%)^{*}$ & $-51.3 \%$ \\
\hline Compound 2 & $253.33 \pm 15.25$ & $202.17 \pm 6.12(-29.6 \%)^{*}$ & $\mid 63.33 \pm 4.31(-46.7 \%)^{*}$ & $135.33 \pm 2.50(-58.2 \%)^{*}$ & $-46.6 \%$ \\
\hline Compound 3 & $280.5 \pm 13.54$ & $207.17 \pm 5.12(-27.9 \%)^{*}$ & $|56.5 \pm 5.1|(-49.0 \%)^{*}$ & $|21.67 \pm 1.7|(-62.4 \%)^{*}$ & $-56.6 \%$ \\
\hline Compound 4 & $265.17 \pm 9.48$ & $199.61 \pm 5.67(-30.5 \%)^{*}$ & $162.17 \pm 3.50(-47.1 \%)^{*}$ & $129.67 \pm 2.20(-60.0 \%)^{*}$ & $-51.1 \%$ \\
\hline Compound $\mathbf{5}$ & $266.36 \pm 4.11$ & $206.14 \pm 5.18(-28.3 \%)^{*}$ & $164.17 \pm 4.03(-46.4 \%)^{*}$ & $|3| .17 \pm 3.20(-59.5 \%)^{*}$ & $-50.8 \%$ \\
\hline
\end{tabular}

Notes: $* \mathrm{P}<0.001$, “-” indicates percent reduction; *Statistical significance as compared to the negative control group.

Table 5 Effect of Synthesized Compounds (Each $100 \mathrm{Mg} / \mathrm{Kg}$ ) on Body Weight of STZ-Induced Diabetic Mice

\begin{tabular}{|l|c|c|c|c|c|c|}
\hline \multirow{2}{*}{ Treatment Groups } & \multicolumn{4}{|c|}{ Bodyweight (g) } & \multicolumn{2}{c|}{ Change in Body Weight } \\
\cline { 2 - 7 } & Day 0 & Day 7 & Day I4 & Day 2 I & Compared to DC & From day 0 to 2 I \\
\hline Diabetic control & $25.25 \pm 0.83$ & $24.22 \pm 0.80$ & $23.42 \pm 0.96$ & $22.67 \pm 0.85$ & - & $-10.2 \% * * *$ \\
Glibenclamide (I0 mg/kg) & $25.38 \pm 0.67$ & $25.05 \pm 0.56$ & $25.25 \pm 0.5 I$ & $25.13 \pm 0.47$ & $+10.9 \%$ & $-1.0 \%$ \\
Compound I & $24.78 \pm 0.9$ & $24.60 \pm 1.00$ & $24.17 \pm 0.98$ & $24.05 \pm 0.96$ & $+6.1 \%$ & $-2.9 \%$ \\
Compound 2 & $24.5 \pm 0.76$ & $24.00 \pm 0.77$ & $23.78 \pm 0.86$ & $23.33 \pm 0.84$ & $+3.0 \%$ & $-4.8 \% * *$ \\
Compound 3 & $24.92 \pm 0.56$ & $24.83 \pm 0.54$ & $24.67 \pm 0.71$ & $25.00 \pm 0.63$ & $+10.3 \%$ & $+0.3 \%$ \\
Compound 4 & $24.25 \pm 0.93$ & $23.87 \pm 1.01$ & $23.80 \pm 0.99$ & $24.02 \pm 1.03$ & $+6.0 \%$ & $-0.9 \%$ \\
Compound 5 & $24.77 \pm 0.84$ & $24.38 \pm 0.82$ & $24.25 \pm 0.98$ & $24.50 \pm 0.72$ & $+8.1 \%$ & $-1.1 \%$ \\
\hline
\end{tabular}

Notes: Values are mean \pm SEM, $\mathrm{n}=6$, “+” percent increase, “-” percent decrease, DC- diabetic control, **P<0.0I, ***P<0.00I.

higher activity observed for compound $\mathbf{1}$ over compound $\mathbf{5}$ at similar dose levels.

Furthermore, a comparison of compounds 4 and 5 revealed that substitution of a methoxy group at position 5 by bromine resulted in a significant reduction in antihyperglycemic activity, from $23.6 \%$ to $10.7 \%$ at a dose of $50 \mathrm{mg} / \mathrm{kg}$ and from $32.5 \%$ to $25.4 \%$ at a dose of $100 \mathrm{mg} / \mathrm{kg}$ (Table 2). These results show that incorporation of an electron-donating group at that position is essential to maximize the anti-hyperglycemic activity of chalcones.

In contrast, changing the hydroxyl group from ortho to para position and adding bromine at position $5^{\prime}$ on the benzaldehyde ring did not bring a significant change in reducing postprandial hyperglycemia (Table 3). This was observed by comparing compounds $\mathbf{1}$ and $\mathbf{2}$ with compounds $\mathbf{3}$ and $\mathbf{5}$, respectively. Likewise, changing the position and type of substituents in the aromatic rings did not show a significant difference in reducing fasting glucose levels in STZinduced diabetic mice (Table 4).

\section{Conclusion}

Five chalcone derivatives were synthesized using the Claisen-Schmidt condensation reaction. The compounds were obtained with high purity and good yield (71-81.5\%) and their structure was confirmed using IR, ${ }^{1} \mathrm{H}$ NMR, ${ }^{13} \mathrm{C}$ NMR and DEPT-135 spectroscopic techniques. The OGTT model was carried out using normal mice, and the results showed that compound 3 , at a dose of $100 \mathrm{mg} / \mathrm{kg}$ body weight, was highly active in reducing postprandial hyperglycemia (39\%) compared to glibenclamide (34.5\%) and the rest test compounds. At the same dose level, compounds $\mathbf{1}$ and $\mathbf{4}$ (34.3\% and 32.5\%, respectively) showed comparable efficacy with glibenclamide. In contrast, compounds 5 (25.4\%) and $2(22.5 \%)$ were relatively less effective in reducing postprandial hyperglycemia. In the STZ-induced diabetes model, all the test compounds showed comparable antidiabetic activity with each other and with glibenclamide on each day as compared to the diabetic control group. The antidiabetic activity in terms of the percent reduction in fasting BGL was in the order of compound $3(56.6 \%)>$ compound $1(51.3 \%)>$ compound $4(51.1 \%)>$ compound 
<smiles>COc1cc(/C=C/C(=O)c2ccccc2O)cc(Br)c1O</smiles><smiles>COc1cccc(/C=C/C(=O)c2ccc(Cl)cc2Cl)c1O</smiles><smiles>COc1cccc(/C=C/C(=O)c2ccccc2O)c1O</smiles><smiles>COc1cc(/C=C/C(=O)c2ccc(Cl)cc2Cl)cc(OC)c1O</smiles><smiles>COc1cc(/C=C/C(=O)c2ccc(Cl)cc2Cl)cc(Br)c1O</smiles>

Figure 2 Chemical structure of the synthesized compounds (I-5).

$5(50.8 \%)>$ compound $2(46.6 \%)$. Glibenclamide reduced BGL by $57.2 \%$. In general, our results indicated that all the test compounds could be potential lead compounds in the discovery of potent and effective drugs for the treatment of diabetes mellitus.

\section{Acknowledgment}

The researchers are very grateful to Dr. Gomati (Ph.D. in Phytochemistry, Mekelle University, Ethiopia) for her unlimited help in arranging the purchasing process of chemicals required for the synthesis. Our sincere appreciation also goes to all beloved family of Welday, especially to Tsega Welday, who helped us by investing their money and precious time in searching and buying chemicals. In addition, the researchers acknowledge Addis Ababa University and Addis Pharmaceutical Factory for providing NMR and IR services, respectively. This work is done under Mekelle University as part of MSc thesis. This study was Semere Welday's part of MSc work.

\section{Funding}

This research did not receive any specific grant from funding agencies in the public, commercial, or not-forprofit sectors.

\section{Disclosure}

The authors declare no competing interests in this work.

\section{References}

1. SEMDSA. Guidelines for the management of type 2 diabetes mellitus. JEMDSA. 2017;22(suppl1):S1-S196. 
2. Ogurtsova K, Rocha JD, Huang Y, Linnenkamp U, Guariguata L. Global estimates for the prevalence of diabetes for 2015 and 2040. Diabetes Res Clin Pr. 2017;128:40-50. doi:10.1016/j.diabres.2017.03.024

3. Karuranga S, Cho NH, Ohlrogge AW, et al. IDF Diabetes Atlas: global estimates of diabetes prevalence for 2017 and projections for 2045. Diabetes Res Clin Pract. 2018;138:271-281. doi:10.1016/j.diabres.20 18.02 .023

4. Baynes HW. Classification, pathophysiology, diagnosis and management of diabetes mellitus. $J$ Diabetes Metab. 2015;6(5):1-9. doi:10.4172/2155-6156.1000541

5. William S. Insulin and drugs used to treat diabetes. In: Thomasd LL, David AW, Victoria FR, Zit WS, editors. Foye's Principles of Medicinal Chemistry. 7th edi ed. Lippincott Williams \& Wilkins; 2012:877-903.

6. Chavan B, Gadekar A, Mehta P, Vawhal P, Kolsure A, Chabukswar A. Synthesis \& medicinal significance of chalconesreview. Asian J Biomed Pharm Sci. 2016;6:56.

7. Satyanarayana M, Tiwari P, Tripathi BK, Srivastava AK, Pratap R. Synthesis and antihyperglycemic activity of chalcone based aryloxypropanolamines. Bioorganic Med Chem. 2004;12(5):8 83-889. doi:10.1016/j.bmc.2003.12.026

8. Xiao J, Kai G, Yamamoto K, Chen X. Advance in dietary polyphenols as $\alpha$-glucosidases inhibitors: a review on structure-activity relationship aspect. Crit Rev Food Sci Nutr. 2013;53(8):818-836. doi:10.1080/10408398.2011.561379

9. Mahapatra D, Bharti S, Asati V. Chalcone scaffolds as anti-infective agents: structural and molecular target perspectives. Eur J Med Chem. 2015;101:496-524. doi:10.1016/j.ejmech. 2015.06.052

10. Park H, Bak E, Woo G, et al. Licochalcone E has an antidiabetic effect. J Nutr Biochem. 2012;23(7):759-767. doi:10.1016/j.jnutbio. 2011.03.021

11. Chinthala Y, Thakur S, Tirunagari S, et al. Synthesis, docking and ADMET studies of novel chalcone triazoles for anti-cancer and anti-diabetic activity. Eur $J$ Med Chem. 2015;93:564-573. doi:10.1016/j.ejmech.2015.02.027

12. Sobhi GM, Riyadh M, Abdalla M. Solvent-drop grinding method: efficient synthesis, DPPH radical scavenging and anti-diabetic activities of chalcones, bis-chalcones, azolines, and bis-azolines. Curr Org Synth. 2015;12(2):220-228. doi:10.2174/1570179412666150122230447

13. Sun H, Wang D, Song X, et al. Natural prenylchalconaringenins and prenylnaringenins as antidiabetic agents: $\alpha$ glucosidase and $\alpha$-amylase inhibition and in Vivo antihyperglycemic and antihyperlipidemic effects. J Agric Food Chem. 2017;65(8):1574-1581. doi:10.1021/acs.jafc.6b05445

14. Yadav P, Lal K, Kumar A, Guru S, Jaglan S, Bhushan S. Green synthesis and anticancer potential of chalcone linked-1, 2, 3-triazoles. Eur J Med Chem. 2017;126:944-953. doi:10.1016/j.ejmech.2016.11.030

15. Going CC, Tailor D, Kumar V, et al. Quantitative proteomic profiling reveals key pathways in the anti-cancer action of methoxychalcone derivatives in triple negative breast cancer. J Proteome Res. 2018;17 (10):3574-3585. doi:10.1021/acs.jproteome.8b00636
16. Ugwu D, Ezema B, Okoro U, et al. Synthesis and pharmacological applications of chalcones: review. Int J Chem Sci. 2015;13 (1).

17. Suwito H, Pudjiastuti P, Fanani M, et al. Design and synthesis of chalcone derivatives as inhibitors of the ferredoxin-Ferredoxin$\mathrm{NADP}+$ reductase interaction of plasmodium falciparum: pursuing new antimalarial agents. Molecules. 2014;19(12):21473-21488. doi:10.3390/molecules191221473

18. Rossi M, Caruso F, Crespi E, et al. Probing antioxidant activity of 2'hydroxychalcones: crystal and molecular structures, in vitro antiproliferative studies and in vivo effects on glucose regulation. Biochimie. 2013;95(10):1954-1963. doi:10.1016/j.biochi.2013.07.002

19. Bui T, Nguyen N, Dang P, Nguyen H, Nguyen M. Design and synthesis of chalcone derivatives as potential non-purine xanthine oxidase inhibitors. Springerplus. 2016;5(1):1789. doi:10.1186/ s40064-016-3485-6

20. Khan S, Asiri A. Green synthesis, characterization and biological evaluation of novel chalcones as anti bacterial agents. Arab J Chem. 2017;10:S2890-S2895. doi:10.1016/j.arabjc.2013.11.018

21. Sahu N, Balbhadra S, Choudhary J, Kohli D. Exploring pharmacological significance of chalcone scaffold: a review. Curr Med. 2012;19(2):209-225

22. Zhuang C, Zhang W, Sheng C, Zhang W, Xing C, Miao Z. Chalcone: a privileged structure in medicinal chemistry. Chem Rev. 2017;117 (12):7762-7810. doi:10.1021/acs.chemrev.7b00020

23. Kumar V, Kumar S, Hassan M, et al. Novel chalcone derivatives as potent Nrf2 activators in mice and human lung epithelial cells. $J$ Med Chem. 2011;54(12):4147-4159. doi:10.1021/jm2002348

24. Gomes M, Muratov E, Pereira M, Peixoto JC. Chalcone derivatives: promising starting points for drug design. Molecules. 2017;22 (8):1210. doi:10.3390/molecules22081210

25. Institute for Laboratory Animal Research. Guide for the Care and Use of Laboratory Animals. $8^{\text {th }}$ ed. Washington, DC; 2011.

26. Deeds M, Anderson J, Armstrong A, et al. Single dose streptozotocin induced diabetes: considerations for study design in islet transplantation models. Lab Anim. 2011;45(3):131-140. doi:10.1258/la.2010.010090

27. Eddouks M, Chattopadhyay D, Zeggwagh NA. Animal models as tools to investigate antidiabetic and anti-inflammatory plants. EvidBased Comple Alter Med. 2012;1-14. doi:10.1155/2012/142087

28. Singh MP, Pathak K. Animal models for biological screening of anti-diabetic drugs. Eur J Exper Bio. 2015;5(5):37-48.

29. OECD/OCDE. No. 425. Acute oral toxicity: up-and-down procedure. OECD guidelines for the testing of chemicals. 2008;1-27.

30. Gaur R, Yadav K, Verma R, Yadav N, Bhakuni R. In vivo anti-diabetic activity of derivatives of isoliquiritigenin and liquiritigenin. Phytomedicine. 2014;21(4):415-422. doi:10.1016/j.phymed.2013.10.015

\section{Publish your work in this journal}

Drug Design, Development and Therapy is an international, peerreviewed open-access journal that spans the spectrum of drug design and development through to clinical applications. Clinical outcomes, patient safety, and programs for the development and effective, safe, and sustained use of medicines are a feature of the journal, which has also been accepted for indexing on PubMed Central. The manuscript management system is completely online and includes a very quick and fair peer-review system, which is all easy to use. Visit http://www. dovepress.com/testimonials.php to read real quotes from published authors. 